$\Gamma$

енетические маркеры развития псориатического поражения суставов у больных псориазом. Часть I: Полиморфизмы генома, не относящиеся к системе HLA

( С Кубанов А.А., Карамова А.Э., Чикин В.В., Вербенко Д.А., Знаменская Л.Ф., Артамонова О.Г. *

Государственный научный центр дерматовенерологии и косметологии

107076, Россия, г. Москва, ул. Короленко, д. 3, стр. 6

У больных псориазом может развиваться поражение суставов, приводящее к их деформации, неподвижности, нарушению функции и инвалидности. Артропатический псориаз (псориатический артрит) является полигенным заболеванием. Персонификациия прогноза заболевания может быть решена с учетом вариабельности множества геномных локусов, с которыми ассоциировано его развитие. В обзоре рассматриваются геномные полиморфизмы, с которыми ассоциируется развитие псориатического артрита, но не псориаза, за исключением полиморфизмов главного комплекса гистосовместимости (HLA). Описаны участки генома, содержащие полиморфизмы, с аллельными вариантами которых ассоциировано как развитие псориатического артрита, так и уменьшение вероятности его возникновения. Получены данные о том, что предрасположенность к развитию псориатического артрита у больных псориазом определяют гены, кодирующие белки, участвующие в воспалении и метаболизме костной ткани.

Ключевые слова: псориатический артрит, генетическая предрасположенность, ассоциативные исследования, Онп, полигенное заболевание.

Конфрликт интересов: авторы декларируют отсутствие явных и потенциальных конфрликтов интересов, связанных с публикацией настоящей статьи.

Источник фринансирования: поисково-аналитическая работа проведена на личные средства авторского коллектива.

Для цитирования: Кубанов А.А., Карамова А.Э., Чикин В.В., Вербенко Д.А., Знаменская Л.Ф., Артамонова О.Г. Генетические маркеры развития псориатического поражения суставов у больных псориазом.

Часть I: Полиморфизмы генома, не относящиеся к системе HLA. Вестник дерматологии и венерологии. 2021;97(4):33-47. doi: https://doi.org/10.25208/vdv1260 


\title{
Genetic markers for psoriatic arthritis in patients with psoriasis. Part I: non-HLA genes
}

\author{
(C) Alexey A. Kubanov, Arfenya E. Karamova, Vadim V. Chikin, Dmitry A. Verbenko, Lyudmila F. Znamenskaya, Olga G. Artamonova*
}

State Research Center of Dermatovenereology and Cosmetology

Korolenko str., 3, bldg 6, 107076, Moscow, Russia

Psoriatic arthritis often develops in patients with psoriasis and can lead to joint deformity, stiffness, dysfunction, and disability. Psoriatic arthritis is a polygenic disease. and the issue of personalizing the prognosis of its development can only be resolved taking into account the variability of plenty genomic loci associated with the development of the disease. The personification of the prognosis of the disease can be solved taking into account the variability of the set of genomic loci with which its development is associated. The review examines genomic polymorphisms associated with the development of psoriatic arthritis not psoriasis, except of HLA polymorphisms. Genome regions containing polymorphisms, allelic variants of which are associated both with the development of psoriatic arthritis and reducing the likelihood of its occurrence, are described. It has been reported that the predisposition to the development of psoriatic arthritis in patients with psoriasis is determined by genes encoding proteins involved in inflammation and bone metabolism.

Keywords: psoriatic arthritis, genetic susceptibility, Genome-Wide Association Study, SNP, polygenic disease.

Conflict of interest: the authors declare that there are no obvious and potential conflicts of interest associated with the publication of this article.

Source of funding: the work was done and published through financing at the place of work of the authors.

For citation: Kubanov AA, Karamova AE, Chikin VV, Verbenko DA, Znamenskaya LF, Artamonova OG. Genetic markers for psoriatic arthritis in patients with psoriasis. Part l: non-HLA genes. Vestnik Dermatologii i Venerologii. 2021;97(4):33-47. doi: https://doi.org/10.25208/vdv1260 
Псориатический артрит (псориаз артропатический) - хроническое воспалительное заболевание суставов, позвоночника и энтезисов, которое может наблюдаться у больных псориазом. Псориатическое поражение суставов развивается у 20-30\% пациентов с псориазом [1]. Сочетание псориатического артрита и псориаза обусловлено значительной общностью патогенеза, ведущую роль в котором играют Th1и Th17-лимфоциты и цитокины фактор некроза опухоли-(TNF)- $\alpha$, интерлейкины-(IL)-12, IL-17, IL-23.

Считается, что первично в дебюте псориатического артрита активируются клетки врожденной иммунной системы - дендритные клетки, натуральные киллерные (NK) клетки, $\gamma \delta$-Т-лимфроциты, лимфоидные клетки врожденного иммунитета, полиморфно-ядерные нейтрофильные лейкоциты и моноциты/макрофаги, которые начинают продуцировать хемокины и цитокины, способствующие развитию воспаления, в том числе TNF- $\alpha$, IL-12 и IL-23 [2-5]. Важным эфффекторным цитокином, принимающим участие в патогенезе псориатического артрита, является TNF- $\alpha$, способствующий рекрутированию и активации полиморфноядерных нейтрофилов и мононуклеарных клеток в очагах поражения, а также продукции ими воспалительных цитокинов. TNF- $\alpha$ действует, связываясь со своими рецепторами на клеточной поверхности и активируя внутриклеточные сигнальные пути, включая транскрипционный фактор NF-kB $[2,9]$.

Под влиянием TNF- $\alpha$, IL-12 и IL-23 происходит активация клеток приобретенного иммунитета - CD8+ Т-лимфоцитов, CD4+ Th1-, Th17-, Th9- и Th22-лимфоцитов, что приводит к увеличению выраженности воспалительной реакции в суставе и ее поддержанию [5].

Аномальная активация воспалительной оси IL-23/ Th17-лимфоциты считается основой патогенеза псориатического артрита [4]. Под влиянием IL-1 $\beta$, IL-6 и трансформирующего фактора роста $\beta$ наивные Т-лимфоциты начинают экспрессировать рецептор интерлейкина-23 IL23R. Связывание IL-23 со своим рецептором IL23R на поверхности Т-лимфоцитов активирует сигнальные пути тирозинкиназы 2 (Туk2) и Янус-киназы 2 (JAK2) с последующей активацией фрактора транскрипции STAT3, который стимулирует продукцию IL-17, а также других цитокинов - IL-21, IL-22, гранулоцитарного колониестимулирующего фрактора и TNF- $\alpha$, путем увеличения экспрессии соответствующих генов. Активация IL23R приводит к диффреренцировке наивных Т-лимфоцитов в Th17-лимфоциты и поддержанию в последующем их фенотипа, так как он нестоек и для своего сохранения требует присутствия IL-23 [5].

Активацией оси IL-23/Th17-лимфоциты при поражениях суставов при псориазе обусловлено повышение содержания в синовиальной жидкости продуцирующих IL-17 CD4+ и CD8+ Т-лимфоцитов, которые являются основным источником IL-17, IL-2, IL-6, интерферона- $\gamma$ и IL-22 [6]. Уровень IL-17+ CD8+ T-лимфоцитов в синовиальной жидкости коррелирует с активностью и прогрессированием суставных изменений при псориатическом артрите [7]. Воспалительный эфрфект IL-17 реализуется через активацию внутриклеточных сигнальных путей, включающих ядерный фрактор-kB (NF-kB) [2, 5, 8].

Цитокины, принимающие участие в развитии воспалительной реакции при псориатическом артрите, способствуют также формированию патологических изме- нений хрящей и костей [6]. В хрящевой ткани у больных псориатическим артритом происходят деструктивные изменения. Разрушение хряща обусловлено повышением содержания TNF- $\alpha$, который увеличивает продукцию матриксных металлопротеиназ (ММП) макрофрагами [6]. С аномальной активностью воспалительных цитокинов связывается повышение продукции деструктивных протеаз хондроцитами, что приводит к потере протеогликанов, повреждению коллагеновых пучков и в итоге к разрушению хряща $[10,11]$.

Особенность псориатического артрита - ремоделирование костной ткани, которое не ограничивается разрушением кости, но также характеризуется последующим образованием новой костной ткани [8]. Физиологически костный гомеостаз поддерживается равновесием между остеокластами, способными к резорбции кости, и остеобластами, ответственными за фрормирование кости. Это равновесие может нарушаться под действием цитокинов, продукция которых увеличивается при артропатическом псориазе.

TNF- $\alpha$, IL-17 и IL-23 способны индуцировать диффреренцировку моноцитов в остеокласты $[12,13]$. Важное значение в этом процессе имеет лиганд рецептораактиватора ядерного фрактора-kB (RANKL) [13]. Мембранный белок RANKL экспрессируется на поверхности Th17-лимфроцитов, его экспрессия может увеличиваться под действием ряда цитокинов, в том числе TNF- $\alpha$, IL-1 $\beta$, IL-6, IL-15, IL-17, IL-23 [4, 13]. Роль мембранного белка Th17-лимсоцитов RANKL в патогенезе псориатического артрита состоит в его способности связываться с рецептором-активатором ядерного фрактора-kB (RANK) на поверхности моноцитов/макрофрагов субхондральной части кости и стимулировать их дифрференцировку в остеокласты $[4,13]$. Кроме того, присутствующий на поверхности моноцитов остеокласт-ассоциированный рецептор (OSCAR) в присутствии TNF- $\alpha$ потенцирует действие RANKL, тем самым усиливая остеокластогенез [14]. Активированные остеокласты начинают секретировать ферменты деградации костного матрикса - тартрат-резистентную кислую фоссратазу (TRAP), матриксную металлопротеиназу 9 (MМP9) и катепсин К (CatK), которые подвергают резорбции минерализованную кость. В результате на стыке кость-паннус и в субхондральной части кости у больных псориатическим артритом фрормируются эрозии.

С другой стороны, IL-22 при псориатическом артрите способствует пролиферации мезенхимальных стволовых клеток и их дифреренцировке в остеобласты [8]. IL-22 индуцирует остеопролиферацию в энтезисах и надкостнице через активацию STAT3 в остеобластах, вызывая образование новой костной ткани, проявляющееся фрормированием энтезофитов, шпор, анкилозов, сращением периферических суставов, а также образованием синдесмофитов в осевом скелете и изменениями в крестцово-подвздошных суставах $[5,15,16]$.

Патологические процессы, развивающиеся при псориатическом артрите, проявляются поражением различных суставных структур. Псориатический артрит может проявляться периферическим артритом с обязательным развитием синовита, воспалительным поражением аксиальных структур - тел позвонков (спондилит) и подвздошно-крестцовых сочленений (сакроилеит), энтезисов, то есть участков прикрепления сухожилий к костям (энтезит). Возможно также развитие сочетанного воспаления межфаланговых суставов 
(артрит) и сухожилий сгибателей/разгибателей пальца (теносиновит), которое характеризует собой воспаление пальца - дактилит. Общие признаки различных клинических фрорм псориатического артрита - воспалительная боль, которая усиливается в покое и уменьшается при движениях, припухлость, ограничение подвижности суставов, возможно появление утренней скованности $[17,18]$.

В случае прогрессирования псориатического артрита возможно развитие неблагоприятных для здоровья пациентов исходов. Примерно у половины пациентов развивается эрозивное поражение суставов [19, 20]. В отсутствие лечения возможно развитие деформаций и неподвижности суставов, что сопровождается выраженными функциональными нарушениями, приводящими к стойкой утрате трудоспособности - инвалидности [21]. Деструкция суставов у пациентов с псориатическим артритом может развиться всего через несколько лет после начала заболевания [22-24]. В ретроспективном исследовании показано, что задержка диагностики псориатического артрита всего на 6 месяцев связана с ухудшением долгосрочных рентгенологических и фуункциональных исходов [18, 25], что определяет важное значение ранней диагностики псориатического артрита и выявления групп риска его развития, прежде всего в отношении больных псориазом.

В связи с этим определение молекулярно-биологических маркеров развития псориатического артрита у больных псориазом представляется важной задачей. Одним из подходов к поиску таких маркеров является изучение ассоциаций заболеваний с геномным полиморфизмом, маркируемым однонуклеотидными полиморфизмами. Обнаруженные ассоциации верифрицируют, то есть проводят оценку возможности прогнозирования развития заболевания на основании данных об аллельных вариантах одного или нескольких полиморфных локусов. Дальнейший переход к персонификации прогнозирования требует также учета этнического происхождения пациента, поскольку многочисленные исследования показывают ассоциацию различного набора однонуклеотидных полиморфизмов с заболеванием в зависимости от происхождения исследуемой популяции, для чего возможно использование геномных биомаркеров - полиморфных участков генов, участвующих в фрормировании предрасположенности к развитию этого заболевания. В связи с этим был проведен анализ литературы с целью определения геномных маркеров, не относящихся к системе главного комплекса гистосовместимости (HLA), способных указывать на предрасположенность больных псориазом к развитию псориатического поражения суставов.

\section{Раздел 1}

Геномные биомаркеры и риск артропатического псориаза

В настоящее время известно более 50 не связанных с системой HLA участков генома, ассоциированных с предрасположенностью к псориатическому артриту [26]. Для 30 таких участков выявлены также ассоциации с возникновением других заболеваний, в том числе с псориазом [26]. Тем не менее для прогнозирования развития псориатического артрита у больных псориазом оптимальным является применение генетических полиморфизмов, носительство которых ассоциировано только с псориатическим артритом, но не с псориазом, или локусов, ассоциация которых c артритом более выражена, чем с псориазом.

В последнее время проведены исследования, показавшие существование однонуклеотидных полиморфризмов (ОНП), определяющих различия в предрасположенности к псориазу и псориатическому артриту [27, 28]. Среди них с развитием псориатического артрита оказались ассоциированы ОНП, расположенные в генах IL23R (rs2201841, rs12044149), FBXL19 (rs10782001), IL12B (rs2082412), CCR2 (rs1799864), CSF2 (rs715285), PTPN22 (rs2476601), IL13 (rs1800925, rs20541, rs848), TNFAIP3 (rs9321623), B3GNT2 (rs10865331) PPARG (rs1801282) и KIR2DS2 [27, 28] (таблица).

Выявлено влияние ОНП гена IL23R на предрасположенность больных псориазом к развитию псориатического артрита. Ген IL23R кодирует субъединицу IL-23R рецептора IL-23, и в результате альтернативного сплайсинга образуется по меньшей мере шесть вариантов рецепторного белка IL-23R [29]. С экспрессией IL23R связана эффективность клеточного ответа на IL-23 Т-лимфроцитами памяти, NK-клетками, моноцитами и дендритными клетками [30]. В связи с этим полиморфизмы гена IL23R могут влиять на выраженность воспалительной реакции, определяемой этими клетками. В гене IL23R обнаружены ОНП, аллельные варианты которых ассоциированы и с развитием псориатического артрита, и обладающие протективным эффректом в этом отношении.

Показано, что носители генотипов rs12044149*TG и rs2201841*GA, расположенных в интронах гена IL23R, имеют более высокий риск развития псориатического артрита, чем псориаза [31, 32]. Поскольку альтернативный сплайсинг происходит с образованием как минимум шести вариантов мРНК, генерирующих различные изоформы рецепторного белка [29], интронные полиморфизмы могут влиять на результаты сплайсинга и образование определенных изоформ белка-рецептора [33]. Возможны также другие механизмы, способные формировать предрасположенность к воспалительным заболеваниям у носителей различных аллелей ОНП гена IL23R. Эти механизмы связаны с устойчивостью вариантов МРНК, образующейся при экспрессии гена $I L 23 R$, к воздействию микроРНК, вызывающих ее деградацию и уменьшающих количество образующегося белка IL23R [34].

При оценке результатов исследований полиморфризма rs2201841 гена IL23R, участвующего в фрормировании предрасположенности к псориатическому артриту, выявлена высокая степень популяционной изменчивости. У людей европейского и африканского происхождения основным аллелем этого полиморфизма является rs2201841*A, тогда как у лиц азиатского происхождения основной аллель - rs2201841*C [33]. Следовательно, необходимо учитывать популяционную гетерогенность при анализе влияния этого полиморфризма на предрасположенность к развитию псориатического артрита.

Выявлены также варианты гена IL23R, уменьшающие вероятность развития псориатического поражения суставов. Протективный эффрект в отношении возникновения псориатического артрита был обнаружен у миссенс-варианта IL23R rs11209026*(G>A) [35]. Известными в настоящее время механизмами, которые обуславливают проявление протективного эффректа 
Таблица. Генетические маркеры, определяющие предрасположенность к развитию псориатического артрита у больных псориазом

Table. Genetic markers determining susceptibility to psoriatic arthritis in patients with psoriasis

\begin{tabular}{|c|c|c|c|c|c|c|}
\hline $\begin{array}{c}\text { Ген/локализация в } \\
\text { хромосоме }\end{array}$ & Название гена & Функция молекул & $\begin{array}{l}\text { SNP } \\
\text { rs number }\end{array}$ & $\begin{array}{l}\text { Ассоциированный } \\
\text { с развитием } \\
\text { псориатического } \\
\text { артрита аллельный } \\
\text { вариант, генотип } \\
\text { либо гаплотип }\end{array}$ & $\begin{array}{l}\text { Отношение шансов } \\
\text { (OR) }\end{array}$ & Ссылка \\
\hline B3GNT2/2p15 & $\begin{array}{l}\text { beta1,3- } \\
\text { N-acetyl- } \\
\text { glucosaminyl- } \\
\text { transferase } 2\end{array}$ & $\begin{array}{c}\text { Бета-1,3-N-ацетил-глю- } \\
\text { козаминилтрансфераза } 2 \\
\text { участвует в метаболизме } \\
\text { гликозаминогликанов }\end{array}$ & rs10865331 & A & $\begin{array}{c}\text { OR }=1,39 \\
\text { в Испании, } \\
\text { OR }=1,22 \\
\text { в Северной } \\
\text { Америке (A vs G) }\end{array}$ & $\begin{array}{l}\text { Aterido A, } \\
\text { Canete JD, } \\
\text { Tornero J et al., } \\
2019\end{array}$ \\
\hline CCR2/3p21.31 & $\begin{array}{l}\text { C-C motif } \\
\text { chemokine } \\
\text { receptor } 2\end{array}$ & $\begin{array}{l}\text { Рецептор хемокина CCL2, } \\
\text { стимулирующего хемотак- } \\
\text { сис моноцитов, дендрит- } \\
\text { ных клеток, Т-лимфоцитов }\end{array}$ & rs1799864 & A & Не рассчитывали & $\begin{array}{l}\text { Soto-Sanchez J, } \\
\text { Santos-Juanes J, } \\
\text { Coto-Segura P } \\
\text { et al., } 2010\end{array}$ \\
\hline CSF2IP4HA2/5q31.1 & $\begin{array}{c}\text { Colony } \\
\text { stimulating } \\
\text { factor } 2 \text { I Prolyl } \\
\text { 4-Hydroxylase } \\
\text { Subunit Alpha 2 }\end{array}$ & $\begin{array}{c}\text { Гранулоцитарно-макро- } \\
\text { фагальный колониести- } \\
\text { мулирующий фактор } \\
\text { способствует активации } \\
\text { клеток миелоидного про- } \\
\text { исхождения и развитию } \\
\text { воспалительной реакции I } \\
\text { Пролил-4-гидроксилаза } \\
\text { субъединица } \alpha 2 \text { участвует } \\
\text { в ремоделировании вне- } \\
\text { клеточного матрикса }\end{array}$ & rs715285 & G & $\begin{array}{l}\mathrm{OR}=1,25 \\
(\mathrm{~A} \text { vs } \mathrm{G})\end{array}$ & $\begin{array}{c}\text { Bowes J, } \\
\text { Budu-Aggrey A, } \\
\text { Huffmeier U et al., } \\
2015\end{array}$ \\
\hline IFIH1/2q24.2 & $\begin{array}{l}\text { interferon } \\
\text { induced with } \\
\text { helicase C } \\
\text { domain } 1\end{array}$ & $\begin{array}{c}\text { Цитоплазматическая } \\
\text { РНК-хеликаза распо- } \\
\text { знает вирусную РНК, что } \\
\text { активирует противови- } \\
\text { русный иммунитет через } \\
\text { активацию NF-kB и запуск } \\
\text { продукции интерферонов } \\
\text { бета и альфа }\end{array}$ & rs35667974 & A & $\mathrm{OR}=0,47(\mathrm{G}$ vs $\mathrm{A})$ & $\begin{array}{l}\text { Budu-Aggrey A, } \\
\text { Bowes J, } \\
\text { Stuart PE et al., } \\
2017\end{array}$ \\
\hline \multirow{4}{*}{ IL23R/1p31.3 } & \multirow{4}{*}{ IL-23 receptor } & \multirow{4}{*}{ Рецептор IL-23 } & rs2201841 & A & $\begin{array}{c}\mathrm{OR}=1,10-\text { при } \\
\text { сравнении } \\
\text { с больными } \\
\text { псориазом (A vs G) }\end{array}$ & $\begin{array}{l}\text { Stuart PE, } \\
\text { Nair RP, } \\
\text { Tsoi LC et al., } \\
2015\end{array}$ \\
\hline & & & rs12044149 & TG & $\begin{array}{c}\mathrm{OR}=1,296-\text { при } \\
\text { сравнении } \\
\text { с контролем, } \\
\mathrm{OR}=1,196-\text { при } \\
\text { сравнении } \\
\text { с больными } \\
\text { псориазом (G vs T) }\end{array}$ & $\begin{array}{l}\text { Stuart PE, } \\
\text { Nair RP, Tsoi LC } \\
\text { et al., } 2015\end{array}$ \\
\hline & & & rs12044149 & $\mathrm{T}$ & $\begin{array}{c}\text { OR = 1,3-при } \\
\text { сравнении } \\
\text { с больными } \\
\text { псориазом (G vs T) }\end{array}$ & $\begin{array}{c}\text { Budu-Aggrey A, } \\
\text { Bowes J, Loehr S } \\
\text { et al., } 2016\end{array}$ \\
\hline & & & rs11209026 & G & $\begin{array}{c}\mathrm{OR}=0,735 \\
(\mathrm{~A} \text { vs } \mathrm{G})\end{array}$ & $\begin{array}{l}\text { Loures MA, } \\
\text { Alves HV, } \\
\text { de Moraes AG } \\
\text { et al., } 2019\end{array}$ \\
\hline \multirow{3}{*}{ IL12B/5q33.3 } & \multirow{3}{*}{ IL-12B } & \multirow{3}{*}{$\begin{array}{c}\text { Субъединица p40 IL-12 } \\
\text { и IL-23 необходима для } \\
\text { функционирования } \\
\text { провоспалительных цито- } \\
\text { кинов IL-12 и IL-23 }\end{array}$} & rs2082412 & G & $\begin{array}{c}\text { OR = 0,7-при } \\
\text { сравнении } \\
\text { c контролем } \\
\text { (A vs G, у китайцев) }\end{array}$ & $\begin{array}{l}\text { Yang Q, } \\
\text { Liu H, Qu L } \\
\text { et al., } \\
2013\end{array}$ \\
\hline & & & rs6887695 & G & $\begin{array}{l}\mathrm{OR}=1,331 \\
(\mathrm{C} \text { vs } \mathrm{G})\end{array}$ & $\begin{array}{l}\text { Loures MA, } \\
\text { Alves HV, } \\
\text { de Moraes AG } \\
\text { et al., } 2019\end{array}$ \\
\hline & & & rs3212227 & A & $\begin{array}{l}\mathrm{OR}=0,753 \\
(\mathrm{C} \text { vs } \mathrm{A})\end{array}$ & $\begin{array}{c}\text { Alves HV, } \\
\text { de Moraes AG } \\
\text { et al., } 2019\end{array}$ \\
\hline
\end{tabular}


Продолжение таблицы

\begin{tabular}{|c|c|c|c|c|c|c|}
\hline $\begin{array}{c}\text { Ген/локализация в } \\
\text { хромосоме }\end{array}$ & Название гена & Функция молекул & $\begin{array}{c}\text { SNP } \\
\text { rs number }\end{array}$ & $\begin{array}{c}\text { Ассоциированный } \\
\text { с развитием } \\
\text { псориатического } \\
\text { артрита аллельный } \\
\text { вариант, генотип } \\
\text { либо гаплотип }\end{array}$ & $\begin{array}{c}\text { Отношение шансов } \\
\text { (OR) }\end{array}$ & Ссылка \\
\hline \multirow{6}{*}{ IL13/5q31.1 } & \multirow{6}{*}{ IL-13 } & \multirow{6}{*}{$\begin{array}{c}\text { IL-13 участвует в актива- } \\
\text { ции Th2-лимфоцитов и тем } \\
\text { самым стимулирует разви- } \\
\text { тие Th2-воспалительной } \\
\text { реакции }\end{array}$} & \multirow{3}{*}{ rs1800925 } & C & $\begin{array}{c}\text { OR = 1,28 при } \\
\text { сравнении } \\
\text { с псориазом без } \\
\text { псориатического } \\
\text { артрита (T vs C) }\end{array}$ & $\begin{array}{l}\text { Eder L, } \\
\text { Chandran V, } \\
\text { Pellett F } \\
\text { et al., } 2011\end{array}$ \\
\hline & & & & C & $\begin{array}{c}\text { OR = 1,33 при } \\
\text { сравнении } \\
\text { с псориазом без } \\
\text { псориатического } \\
\text { артрита (T vs C) }\end{array}$ & $\begin{array}{l}\text { Bowes J, Eyre S, } \\
\text { Flynn E } \\
\text { et al., } 2011\end{array}$ \\
\hline & & & & CC & $\mathrm{OR}=0,4(\mathrm{C}$ vs $\mathrm{T})$ & $\begin{array}{l}\text { Duffin KC, } \\
\text { Freeny IC, } \\
\text { Schrodi SJ } \\
\text { et al., } 2009\end{array}$ \\
\hline & & & \multirow[b]{2}{*}{ rs20541 } & G & $\begin{array}{c}O R=1,27 \\
(G G \text { vs GC+CC) }\end{array}$ & $\begin{array}{l}\text { Bowes J, Eyre S, } \\
\text { Flynn E } \\
\text { et al., } 2011\end{array}$ \\
\hline & & & & GG & $\begin{array}{c}O R=1,64 \\
(G G \text { vs } G C+C C)\end{array}$ & $\begin{array}{l}\text { Eder L, } \\
\text { Chandran V, } \\
\text { Pellett F et al., } \\
2011\end{array}$ \\
\hline & & & rs848 & CC & $\begin{array}{c}O R=1,61 \\
(C C \text { vs } A C+A A)\end{array}$ & $\begin{array}{l}\text { Eder L, } \\
\text { Chandran V, } \\
\text { Pellett F } \\
\text { et al., } 2011\end{array}$ \\
\hline PPARG/3p25.2 & $\begin{array}{l}\text { Peroxisome } \\
\text { proliferator- } \\
\text { activated } \\
\text { receptor-gamma } \\
\text { (PPAR-gamma) }\end{array}$ & $\begin{array}{c}\text { Рецептор, активируемый } \\
\text { пролифератором перок- } \\
\text { сисом, гамма (PPAR- } \gamma \text { ) } \\
\text { может подавлять нео- } \\
\text { ангиогенез и уменьшать } \\
\text { продукцию TNF- } \alpha \text {, снижая } \\
\text { таким образом выражен- } \\
\text { ность воспалительной } \\
\text { реакции }\end{array}$ & rs1801282 & C & $\mathrm{OR}=0,62(\mathrm{G}$ vs $\mathrm{C})$ & $\begin{array}{l}\text { Butt C, Gladman D, } \\
\text { Rahman P, } \\
2006\end{array}$ \\
\hline & $\begin{array}{c}\text { Protein tyrosine } \\
\text { phosphatase, }\end{array}$ & $\begin{array}{c}\text { Белок лимфоид- } \\
\text { специфическая фросфра- } \\
\text { таза (lymphoid-specific }\end{array}$ & & & $\mathrm{OR}=1,32(\mathrm{C}$ vs $\mathrm{T})$ & $\begin{array}{c}\text { Bowes J, Loehr S, } \\
\text { Budu-Aggrey A } \\
\text { et al., } 2015\end{array}$ \\
\hline PTPN22/1p13.2 & $\begin{array}{c}\text { non-receptor } \\
\text { type, 22; } \\
\text { белок- тиро- } \\
\text { зинфоосфатаза, } \\
\text { протеин-тиро- } \\
\text { зинфоссфатаза } \\
\text { нерецепторный- } \\
\text { тип, } 22\end{array}$ & $\begin{array}{c}\text { экспрессируется на } \\
\text { м- и В-лимфоцитах, } \\
\text { лоноцитах, нейтрофи- } \\
\text { лах, дендритных клетках } \\
\text { и натуральных (естествен- } \\
\text { ных) клетках-киллерах } \\
\text { и опосредует негативную } \\
\text { регуляцию Т-клеточного } \\
\text { сигнального пути }\end{array}$ & rs2476601 & $\mathrm{T}$ & $\mathrm{OR}=1,16(\mathrm{C}$ vs $\mathrm{T})$ & $\begin{array}{l}\text { Stuart PE, } \\
\text { Nair RP, Tsoi LC } \\
\text { et al., } 2015\end{array}$ \\
\hline TNFAIP3/6q23.3 & $\begin{array}{l}\text { Tumor necrosis } \\
\text { factor-alpha- } \\
\text { induced } \\
\text { protein 3; проте- } \\
\text { ин 3, индуциро- } \\
\text { ванный TNF- } \alpha\end{array}$ & $\begin{array}{c}\text { Белок A20 (протеин 3) - } \\
\text { негативный регулятор } \\
\text { NF-кB сигнального пути, } \\
\text { контролирующего процесс } \\
\text { транскрипции провоспа- } \\
\text { лительных цитокинов }\end{array}$ & rs9321623 & C & $\begin{array}{c}\text { OR = 1,172 - при } \\
\text { сравнении } \\
\text { с больными } \\
\text { псориазом (T vs C) } \\
\text { OR = 1,201- } \\
\text { при сравнении } \\
\text { с контролем }\end{array}$ & $\begin{array}{l}\text { Stuart PE, } \\
\text { Nair RP, Tsoi LC et } \\
\text { al., } 2015\end{array}$ \\
\hline $\begin{array}{l}\text { FBXL19/ } \\
16 p 11.2\end{array}$ & $\begin{array}{l}\text { F-box and } \\
\text { leucine rich } \\
\text { repeat protein } 19\end{array}$ & $\begin{array}{c}\text { Предположительно белок } \\
\text { FBXL19 может способство- } \\
\text { вать активации фактора } \\
\text { транскрипции NF-kB }\end{array}$ & rs10782001 & $\mathrm{G}$ & $\begin{array}{c}\text { OR = 1,12 - при } \\
\text { сравнении } \\
\text { с больными } \\
\text { псориазом (A vs G) }\end{array}$ & $\begin{array}{l}\text { Stuart PE, } \\
\text { Nair RP, } \\
\text { Ellinghaus E, } \\
2010\end{array}$ \\
\hline
\end{tabular}


этих вариантов гена IL23R, являются снижение стабильности образующегося белка IL-23R или нарушение его созревания в эндоплазматическом ретикулуме, что приводит к ослаблению сигналов, передаваемых через IL-23R, и, соответственно, к ослаблению скорости активации факторов транскрипции STAT3 и STAT4 $[36,37]$.

Обнаружено, что с развитием псориатического артрита ассоциируются полиморфизмы гена IL 12B. Ген IL12B кодирует субъединицу p40, входящую в состав гетеродимерных цитокинов IL-12 и IL-23, из которых наибольший вклад в развитие воспаления отводится IL-23 [37]. Метаанализ позволил обнаружить повышение риска развития псориатического артрита у носителей генотипа rs6887695 IL 12B ${ }^{\star} \mathrm{C}>\mathrm{G}$ (отношение шансов - 1,331) [35]. В китайской популяции выявлена ассоциация псориатического артрита с минорным аллелем rs2082412*A в гене IL 12B (отношение шансов $0,7)$ [38]. В то же время в европейской популяции существование ассоциации полиморфизма IL 12B rs2082412 с развитием псориатического артрита не подтвердилось даже при поиске методом полногеномного анализа ассоциаций GWAS [27, 31].

Проведенный метаанализ показал наличие сниженного риска развития псориатического артрита у индивидов с аллельным вариантом полиморфизма гена IL12B rs3212227*C. Показано, что генотипы CC и CA уменьшают вероятность развития псориатического поражения суставов (отношение шансов $\mathrm{OR}=0,526$ - для генотипов CC vs $\mathrm{AA}, \mathrm{OR}=0,745$ - для генотипов $\mathrm{CA}$ vs $\mathrm{AA}, \mathrm{OR}=0,722$ - при сравнении CC + CA vs AA) [35].

Более значимая ассоциация с псориатическим артритом, чем с псориазом, найдена для однонуклеотидного полиморфизма гена TNFAIP3 rs9321623 (C/T) [31]. Ген TNFAIP3 кодирует белок А20, также известный как TNF- $\alpha$-индуцируемый белок 3 (TNFAIP3) [39]. Белок A20 связывается с белками сигнального пути NF-kB, в результате снижается активность транскрипционного фрактора NF-кB и подавляется внутриклеточное прохождение сигнала, индуцированного цитокинами TNF- $\alpha$, IL-1, IL-17 [40-43]. Полученные авторами данные позволяют рассматривать белок А20 как негативный регулятор сигнального пути NF-кB [44]. Мутации гена TNFAIP3 могут ослабить негативную регуляцию сигнального пути NF-кB белком A20, что приведет К повышению продукции провоспалительных цитокинов, включая TNF- $\alpha$, IL -1 $\beta$, IL-6, IL-18 [45]. Подтверждением данной гипотезы служат эксперименты, в которых показано, что у мышей с дефицитом белка А20 постоянно сохраняется активированным NF-кB, увеличивается уровень воспалительных цитокинов в сыворотке крови, повышается продукция TNF- $\alpha$ макрофрагами, активируются процессы остеокластогенеза и развивается эрозивный полиартрит [39, 46]

Обнаружена ассоциация с развитием псориатического артрита у полиморфизма гена PTPN22 rs2476601 $(1858 \mathrm{C}>\mathrm{T})$. Ген PTPN22 кодирует протеин-тирозинфосфатазу, нерецепторный тип 22 (лимфоидный) (PTPN22), которую называют также тирозинфосфатазой лимфоцитов. Белок PTPN22 подавляет передачу сигнала Т-клеточного рецептора и является мощным ингибитором активации Т-лимфоцитов [47-49]. Полиморфизм $1858 \mathrm{C}>\mathrm{T}$ гена PTPN22 характеризуется заменой аминокислоты аргинина (R) в положении 620 на триптофан (W) - R620W [50]. Обнаружено, что аллельный вариант
rs2476601*T - генетический фрактор риска развития псориатического артрита [51]: среди больных псориатическим артритом чаще (в 30\%) выявлялись носители генотипов СТ или ТТ по сравнению с популяционным контролем (в 22\%) (OR = 1,49). Этот фракт подтвержден и в других исследованиях: так, аллель Т чаще обнаруживался при псориатическом артрите (у 16,0\% пациентов), чем в популяционном контроле (в 11,9\% случаев) $(\mathrm{OR}-1,41)$ [51].

Эти данные были подтверждены исследованием расширенной выборки больных псориатическим артритом ( $n=3139)$ : выявлена ассоциация полиморфизма rs2476601*T гена PTPN22 с риском развития псориатического артрита (OR $=1,32)$, при этом ассоциации данного полиморфизма с развитием псориаза не найдено [52]. Значимость ассоциации полиморфизма rs2476601 в гене PTPN22 с развитием псориатического артрита была подтверждена также в полногеномных исследованиях ассоциаций (GWAS) [31]. Обнаружена значимая ассоциация развития при псориатическом артрите дактилита с носительством полиморфизма rs2476601*T (отношение шансов - 2,58) [51]. Показано также, что у носителей предрасполагающего аллеля $\mathrm{rs}_{2476601^{*} \mathrm{~T}}$ имелось значительно больше деформированных суставов, число которых составило в среднем 5,9 $\pm 1,2$, по сравнению с 2,8 \pm 0,5 деформированных суставов у лиц, не являющихся носителем предрасполагающего аллеля rs2476601*T) [51].

Влияние полиморфизма R620W гена PTPN22 на течение воспалительной реакции объясняется возможными различиями в интенсивности передачи сигнала TCR, экспрессируемого Т-лимфоцитами, что приводит к разной степени экспансии Т-клеток памяти в ткани и способствует их повреждению, активации врожденного иммунитета с продукцией интерферонов и формированием провоспалительной среды, которая облегчает активацию Т-лимфроцитов [50].

С развитием псориатического артрита связывают также полиморфизмы гена IL13. Ген IL13 кодирует IL-13 - провоспалительный цитокин, продуцируемый преимущественно Тh2-лимфроцитами [53]. Несмотря на то, что воспалительная реакция при псориатическом артрите реализуется в основном Th1-цитокинами, в синовиальной жидкости больных обнаружен высокий уровень Th2-цитокина IL-13 [54-56]. Предполагается, что IL-13 уменьшает выраженность воспалительного процесса в суставе, подавляя активность Th1-лимфоцитов и уменьшая продукцию Th1-цитокинов [55]. Данное предположение подтверждено экспериментально на модели коллаген-индуцированного артрита, в которой была обнаружена способность IL-13 уменьшать выраженность проявлений артрита [57].

Исследование, проведенное у пациентов из Торонто (Канада), выявило значительную ассоциацию между тремя ОНП гена IL13 и псориатическим артритом, но не поражением кожи [58]. Частота встречаемости основных аллелей $\mathrm{rs} 1800925^{\star} \mathrm{C}$, rs $20541^{*} \mathrm{G}$ и rs848* $\mathrm{C}$ оказалась значительно выше у пациентов с псориатическим артритом по сравнению со здоровыми людьми и пациентами с псориазом. Генотип GG полиморфизмa rs20541 гена IL13 встречался у 70,8\% пациентов с псориатическим артритом и у 59,5\% лиц из контрольной группы (отношение шансов - 1,64). Генотип CC полиморфизма rs848 выявлен у 70,3\% пациентов 
с псориатическим артритом и у 59,7\% лиц из контрольной группы (отношение шансов - 1,61) [58]. Аналогичные данные получены при обследовании пациентов из Великобритании и Ирландии, где выявлена значительная ассоциация между аллелями rs $1800925^{\star} \mathrm{C}$ и rs20541*G и предрасположенностью к развитию псориатического артрита, но не псориаза. Носительство гомозиготного генотипа rs1800925 CC значительно чаще было выявлено у больных псориатическим артритом (в 73,6\% случаев), чем в контрольной группе здоровых лиц (в 67,1\% случаев). Гомозиготы rs $20541^{\star} \mathrm{GG}$ также наблюдались чаще у больных псориатическим артритом (в 72,5\% случаев) по сравнению со здоровыми людьми (в 67,8\%) [59]. На основании приведенных данных авторы указывают, что полиморфизмы гена IL13 могут быть независимыми генетическими маркерами развития псориатического артрита у пациентов с псориазом [58]. При этом было отмечено значительное неравновесие по сцеплению ОНП rs20541*G и rs848*C, (D' =0,98), в то время как сцепление между локусами rs848/rs205541 и rs1800925 выражено умеренно ( $\left.D^{\prime}=0,49\right)$. Величина эфрфекта и уровень значимости ассоциации между гаплотипом rs $1800925^{\star} \mathrm{C} /$ rs20541* $\mathrm{G}$ и вероятностью развития псориатического артрита по сравнению с псориазом оказались выше, чем для любого из этих ОНП в отдельности. Авторы предполагают, что каждый ОНП играет независимую причинную роль в формировании предрасположенности к псориатическому артриту, что объясняет более сильную связь с этим гаплотипом [58].

С этими данными согласуются результаты генотипирования, проведенного при обследовании пациентов с псориатическим артритом в штате Юта (США). Минорные аллели полиморфизмов гена IL13 (rs1800925*T, rs20541*A и rs848*A) ассоциированы со снижением вероятности развития псориатического артрита, причем самой сильной была ассоциация c rs $1800925^{\star} T$ (отношение шансов - 0,4) [60]. Псориатический артрит был выявлен у 15,5\% носителей генотипа rs $1800925^{\star} \mathrm{CT}$ или *ТT и у $32,1 \%$ носителей генотипа rs $1800925^{\star} \mathrm{CC}$ [60].

Вместе с тем при полногеномном исследовании ассоциаций не удалось воспроизвести ассоциации полиморфизмов гена IL13 с развитием псориатического артрита [31].

При обследовании пациентов европейского происхождения с псориатическим артритом, проживающих на острове Ньюфаундленд (Канада), обнаружено, что аллель rs $1801282^{*} \mathrm{G}$ гена PPARG связан со снижением риска развития псориатического артрита (отношение шансов - 0,62) [61]. Ген PPARG кодирует рецептор, активируемый пролифератором пероксисом, гамма (PPAR- $\gamma$ ). Продукт гена PPARG белок PPAR- $\gamma$ может подавлять неоангиогенез и уменьшать экспрессию TNF- $\alpha$, снижая таким образом выраженность воспалительной реакции $[62,63]$. Полиморфизм rs1801282 C>G характеризуется аминокислотной заменой Pro12Ala в белке PPAR- $\gamma$, что приводит к снижению его активности [27]. Частота встречаемости минорного аллеля rs $1801282^{*} \mathrm{G}$ (Pro12Ala) у пациентов с псориатическим артритом (9,0\%) значительно меньше, чем в контрольной группе здоровых лиц (13,8\%) $(\mathrm{OR}=0,62)$ [61]. Тем не менее, хотя в последующих исследованиях обнаруживалась тенденция к снижению риска развития псориатического артрита при носи- тельстве аллеля rs $1801282^{\star} \mathrm{G}$, статистическая достоверность результата не подтвердилась [27, 64].

Повышение предрасположенности к псориатическому артриту может быть связано с полиморфизмом гена FBXL19 rs10782001 (G/A). Ген FBXL19 (F-box and leucine-rich repeat protein 19) кодирует белок FBXL19 из семейства F-box. В полногеномном исследовании ассоциаций было выявлено, что предрасположенность к развитию псориатического артрита у носителей аллеля rs $10782001^{\star} \mathrm{G}$, выше, чем к развитию псориаза (отношение шансов - 1,12) [65]. Предполагается, что значение белка FBXL19 в развитии воспалительной реакции определяется его способностью к активации фрактора транскрипции NF-kB, стимулирующего продукцию воспалительных цитокинов [65].

С развитием псориатического артрита ассоциирован генетический полиморфизм гена CCR2 rs1799864 $(\mathrm{G}>\mathrm{A})$. Ген CCR2 кодирует белок CCR2, который экспрессируется моноцитами, дендритными клетками, эндотелиальными клетками, некоторыми субпопуляциями Т-лимфоцитов и представляет собой рецептор для моноцитарного хемотаксического протеина 1 МСР-1 (хемокина CCL2) [66-69]. Лиганд CCL2 - белок MCP-1 (хемокин CCL2) - мощный фактор хемотаксиса моноцитов, Т-лимфоцитов памяти и дендритных клеток в очаги воспаления. За счет высокого уровня экспрессии CCR2 моноциты, незрелые дендритные клетки и Т-лимфоциты мигрируют в направлении более высокой концентрации провоспалительного хемокина CCL2 [70].

Обнаружена значительно более высокая частота носительства полиморфного варианта rs1799864*A гена CCR2 среди пациентов с псориазом, у которых развился псориатический артрит. Генотипы АA и GA были выявлены у $28 \%$ больных псориазом и псориатическим артритом и значительно реже - у $12 \%$ больных псориазом без псориатического артрита. Авторы предположили, что генотип CCR2 rs1799864*GA - независимый фрактор риска развития псориатического артрита [71].

Развитие псориатического артрита у больных псориазом ассоциировано и с ОНП $\mathrm{rs} 715285^{\star} \mathrm{G}(\mathrm{A}>\mathrm{G})$, расположенным на хромосоме 5q31 между генами CSF2 и P4HA2 (отношение шансов - 1,25) [72]. Ген CSF2 кодирует гранулоцитарно-макрофагальный колониестимулирующий фрактор (ГМ-КСФ). ГМ-КСФ способствует развитию воспалительной реакции, являясь ключевым цитокином, передающим активирующий сигнал от лимфоцитов к тканевым мононуклеарным фрагоцитам [73, 74]. Ген Р4HA2 кодирует субъединицу пролил-4-гидроксилазы $\alpha 2$, которая участвует в регуляции биосинтеза и формировании депозитов коллагена [75]. Р4НА2 индуцирует ремоделирование внеклеточного матрикса в условиях гипоксии [76-78].

Риск развития псориатического артрита может повышаться в случае носительства некоторых вариантов генов иммуноглобулин-подобного рецептора киллерных клеток (KIR). Ig-подобные рецепторы натуральных киллеров кодируются высокополигенным и полиморфным локусом на хромосоме 19q13.4 в пределах $1 \mathrm{Mb}$ комплекса рецепторов лейкоцитов [79]. Идентифицировано 14 экспрессируемых генов KIR: KIR2DL1, KIR2DL2, KIR2DL3, KIR2DL4, KIR2DS1, KIR2DS2, KIR2DS3, KIR2DS4, KIR2DS5, KIR3DL1, KIR3DL2, KIR3DS1, KIR3DL3 и KIR2DL5. Известно также два псевдогена KIR (2DP и 3DP) [80]. 
Функционирование NK-клеток регулируется балансом между активирующими KIR и ингибирующими KIR. NK-клетки поддерживаются в состоянии покоя ингибирующими KIR, которыми являются рецепторы с длинными цитоплазматическими доменами. Рецепторы KIR с короткими цитоплазматическими доменами передают активирующие сигналы. Лигандами рецепторов KIR являются классические молекулы HLA класса I главного комплекса гистосовместимости, и их связывание запускает один из важных механизмов врожденного иммунитета - активацию естественных киллеров и NK-T-клеток. Взаимодействие комплекса генов KIR с разными аллельными вариантами и различными аллелями HLA неодинаково, что может обуславливать степень предрасположенности к воспалительным заболеваниям [81]. Показано, что активация KIR связана с псориатическим артритом [82, 83]. Развитию псориатического поражения суставов могут способствовать отдельные аллельные варианты гена KIR. Обнаружено, что частота встречаемости KIR2DS1 увеличена у больных псориатическим артритом $(54,7 \%)$ в сравнении с выборкой больных псориазом без псориатического артрита $(37,2 \%)$ и здоровыми (33,3\%); возможно, носительство этого варианта предрасполагает к псориатическому артриту [83]. Имеются данные, что носительство гена KIR2DS2 ассоциировано с развитием псориатического артрита (отношение шансов - 1,25), но не с развитием псориаза. Кроме того, при сравнении генотипов больных псориатическим артритом и псориазом была выявлена ассоциация между носительством гена KIR2DS2 и развитием псориатического артрита (отношение шансов - 1,34), что свидетельствует о специфичности ассоциации с KIR2DS2 именно для поражения суставов, но не кожи [80]. Получены также данные, что KIR2DS1 и/или KIR2DS2 являются маркерами псориатического артрита только тогда, когда лиганды $\mathrm{HLA}$ для их гомологичных ингибирующих рецепторов, KIR2DL1 и KIR2DL2/3, отсутствуют [80, 82].

В румынской популяции описана ассоциация псориатического артрита с полиморфизмами генов ERAP1 и ERAP2 [84]. Гены ERAP1 и ERAP2 кодируют аминопептидазы 1 и 2 эндоплазматического ретикулума (ERAP1 и ERAP2). Аминопептидазы ERAP1 и ERAP2 цинк-зависимые фрерменты, которые распознают и обрабатывают разнообразные антигенные пептиды для фрормирования эпитопов с целью представления пептидов-антигенов молекулами MHC класса I (HLA-A, -В и -С) на поверхности антигенпрезентирующих клеток [85]. Поскольку аминопептидазы ERAP1 и ERAP2 играют важную роль в процессинге пептидов-антигенов, презентируемых белками МHC класса I, предполагается, что различные варианты ERAP влияют на предрасположенность к заболеваниям у лиц, несущих только определенные аллели HLA [84].

Установлена значительно большая частота минорного аллеля rs2248374*A гена ERAP2 у больных псориатическим артритом по сравнению с контролем (отношение шансов - 1,45). Носительство данного варианта наблюдалось значительно чаще у больных псориатическим артритом (81\% случаев), чем в группе здоровых лиц (69\% случаев) (отношение шансов 1,99), что позволяет определить аллельный вариант А полиморфизма rs2248374 как фактор риска развития псориатического артрита [84]. Этот эфрфект наиболее выражен у пациентов с HLA-B27-негативным псориа- тическим артритом. Соответственно, альтернативный вариант rs $2248374^{\star} \mathrm{G}$, который характеризуется прекращением экспрессии белка ERAP2 и наблюдался у 18,4\% больных псориатическим артритом и у $31 \%$ лиц в контрольной группе, в которую включали лиц, не страдающих ревматическими заболеваниями и псориазом, был назван протективным в отношении псориатического поражения суставов. Аллель $\mathrm{rs} 2248374^{*} \mathrm{G}$ ассоциируется с образованием укороченной мРHK ERAP2, которая быстро деградирует, что значительно уменьшает уровень экспрессии белков HLA класса I и ослабляет иммунный ответ [86].

При псориазе также существует ассоциация с полиморфизмом rs2248374 гена ERAP2. Однако при псориазе, в отличие от псориатического артрита, у варианта rs2248374*A и генотипа rs2248374AA обнаружен протективный, а не предрасполагающий эффект, причем протективный эффрект проявлялся только у носителей $H L A-C^{\star} 06: 02$, особенно у пациентов с псориазом, дебютировавшим в молодом возрасте [87].

При оценке влияния полиморфизма rs2910686 гена ERAP2 на развитие псориатического артрита было обнаружено, что носители основного аллеля Т (генотипы ТТ и СТ) реже встречались среди больных (77,3\% случаев), чем среди здоровых лиц (87,7\% случаев), что позволяет рассматривать эти генотипы как протективные [84]. Однако выраженность протективного эффректа генотипов ТТ и СТ полиморфизма rs2910686 сочеталась со снижением частоты - HLA-B27 (отношение шансов - 0,41), причем в случае минорного варианта rs2910686*C риск развития HLA-B27-негативного псориатического артрита повышался (отношение шансов - 1,58).

Оценка влияния полиморфизмов гена ERAP1 на развитие псориатического артрита показала, что оно характерно только для носителей HLA-B27. Минорный аллель rs30187*T гена ERAP1 встречался у 52,9\% больных HLA-B27-позитивным псориатическим артритом и значительно реже у лиц из группы HLA-B27-позитивного здорового контроля (29,2\% случаев). Это позволило рассматривать минорный аллель rs30187T как фактор риска развития HLA-B27-позитивного псориатического артрита (отношение шансов - 2,73). Носительство минорного аллеля $\mathrm{rs} 27044^{\star} \mathrm{G}$ гена ERAP1 также значительно чаще встречалось у больных HLA-B27-позитивным псориатическим артритом (40\% случаев), чем в группе HLA-B27-позитивного здорового контроля (24,5\% случаев), что дало возможность считать аллель rs $27044^{\star} \mathrm{G}$ фактором риска развития псориатического артрита у носителей HLA-B27 [84]. Ассоциация полиморфизма rs27524 гена ERAP1 с псориатическим артритом выявлена в китайской популяции, в то время как в выборке испанской популяции подобная ассоциация не обнаружена [38, 88].

С риском развития поражения суставов ассоциирован ОНП гена B3GNT2 rs10865331 (G>A) [28]. K возникновению псориатического артрита, но не псориаза, предрасполагает носительство минорного аллеля rs $10865331^{*} \mathrm{~A}$ (отношение шансов - 1,39 в испанской популяции, 1,22 - в североамериканской) [28]. Имеются данные о значительном влиянии полиморфизма rs10865331*АнаэкспрессиюгенаB3GNT2[89].ГенB3GNT2 кодирует трансмембранный фрермент бета-1,3-N-ацетилглюкозаминилтрансферазу 2 (beta3GnT2) или полилактозаминсинтазу, синтезирующую основную угле- 
водную цепь гликопротеинов [90]. Тем самым ген B3GNT2 участвует в метаболизме гликозаминогликанов - линейных отрицательно заряженных олигосахаридов, которые содержат гиалуроновую кислоту, хондроитина сульфат и кератана сульфат [91]. Гликозаминогликаны - важный компонент протеогликанов и основной компонент хряща, основной ткани-мишени воспалительной деструкции при псориатическом артрите [92, 93]. Предполагается, что деградация хряща при псориатическом артрите может быть вызвана нарушениями метаболизма гликозаминогликанов, который не изменяется при других артритах, таких как ревматоидный артрит [28]. В моделях in vitro показано, что при воздействии провоспалительных цитокинов развивался неконтролируемый протеолиз специфического для хряща протеогликана аггрекана, что приводило к повреждению хряща в суставе [94]. В экспериментах также показано существование опосредованного гликозаминогликанами механизма разрушения хряща, который обусловлен деградацией гиалуроновой кислоты хондроцитами [95]. Получены также данные о влиянии гена B3GNT2 на развитие воспалительной реакции. В экспериментах с нокаутными мышами было показано, что в отсутствие экспрессии гена B3gnt2 происходила избыточная активация макрофагов, Т- и В-лимсроцитов [90, 96].

На предрасположенность к развитию псориатического артрита влияет полиморфный вариант rs35667974 (A>G) гена IFIH1. Описана протективная роль аллеля rs35667974*G (отношение шансов - 0,47), характеризующегося миссенс-мутацией с заменой в полипептидной цепи белка изолейцина на валин [97].

Ген IFIH1 кодирует цитоплазматическую РНК-хеликазу, которая распознает вирусную РНК, что приводит к активации двух сигнальных путей. В результате активации сигнального пути транскрипционного фрактора NF-kB стимулируется синтез ряда провоспалительных цитокинов, второй сигнальный путь запускается через адапторный белок TRAF3 и протеинкиназу TBK1 с последующей активацией двух транскрипционных факторов IRF3 и IRF7, индуцирующих синтез интерферонов бета и альфа соответственно [98-100]. Предполагается, что протективный эфффект полиморфизма IFIH1, наблюдаемый при псориатическом артрите, обусловлен потерей при этом варианте функционального фенотипа, при котором продукция или активность IFIH1 снижается [97].

R. Pollock и coaвт. (2015) при анализе экспрессии ряда генов показали, что биомаркерами развития псориатического артрита могут быть также полиморфизмы генов NOTCH2NL, HAT1, CXCL10 и SETD2 [101]. NOTCH2NL кодирует белок NOTCH2NL - гомолог NOTCH2 (NOTCH2 N-terminal-like (N2N)), который активируется белком RANKL и способствует образованию остеокластов из макрофрагов костного мозга [102, 103]. Обнаружена положительная корреляция уровня экспрессии NOTCH2NL с количеством припухших суставов у больных псориатическим артритом. Ген SETD2 участвует в процессах модификации хроматина. Выявлена отрицательная корреляционная связь между уровнем его экспрессии и значением скорости оседания эритроцитов [101]. Кроме того, предложено в качестве маркеров развития псориатического артрита у больных псориазом рассматривать гены HAT1, кодирующий гистоновую ацетилтранссреразу 1 (НАT1), и CXCL10 (Chemokine (C-X-C motif) ligand 10 (IP-10), koдирующий хемокин CXCL10 [101].

\section{Заключение}

Таким образом, результаты исследований, проводившихся с применением генотипирования и полногеномных исследований ассоциаций, позволили выявить генетические полиморфизмы, с которыми ассоциирован риск развития псориатического артрита в значительно большей степени, чем риск развития псориаза.

Среди генов, с полиморфизмами которых ассоциировано развитие псориатического артрита, описаны гены с различными функциями. Гены IL23R, IL12B, TNFAIP3, PPARG, FBXL19, IFIH1 и предположительно CXCL10, кодирующие белки, которые принимают участие в регуляции сигнальных путей IL23/Th17 и TNF-a/ $\mathrm{NF}-\kappa \mathrm{B}$, ассоциированы с развитием и поддержанием воспалительной реакции при псориатическом артрите. Некоторые гены, с полиморфизмами которых ассоциируется развитие псориатического артрита, определяют выраженность развивающейся воспалительной реакции. К этим генам относятся PTPN22, который ассоциирован с активацией Т-клеточного рецептора, CCR2, кодирующий фактор хемотаксиса моноцитов, Т-лимфоцитов памяти и дендритных клеток в очаги воспаления CCL2, IL13, продукт которого подавляет Th1-иммунные реакции, CSF2, с активностью которого связана активация мононуклеарных фагоцитов в очагах поражения. С развитием псориатического артрита также ассоциируются аллельные варианты генов, влияющие на функционирование белков системы HLA (KIR2DS1, KIR2DS2, ERAP1 и ERAP2). Имеются гены (B3GNT2 и предположительно NOTCH2NL), влияние которых на предрасположенность к псориатическому поражению суставов определяется их эффректом на метаболизм костной или хрящевой ткани. Описаны также гены, которые могут быть ассоциированы с развитием псориатического артрита, но роль которых в патогенезе псориатического артрита еще не определена, например HAT1, кодирующий гистоновую ацетилтрансферазу 1.

Выявление ассоциации определенных генетических полиморфизмов с развитием псориатического артрита, но не псориазом позволяет прогнозировать развитие поражения суставов у больных псориазом. Оценивая влияние генетических полиморфизмов на предрасположенность к псориатическому артриту, следует учитывать, что оно может быть противоположным. Риск развития поражения суставов у больных псориазом при носительстве определенных генетических полиморфизмов может как увеличиваться, так и уменьшаться, если генетический полиморфизм ассоциирован с его снижением.

Различная частота встречаемости аллелей, способствующих развитию заболевания в различных этнических популяциях, делает полученные результаты актуальными в отношении лишь тех популяций, для которых получены данные. Поэтому проведение исследований генетической предрасположенности к развитию псориатического артрита у больных псориазом необходимо в отношении различных популяций. В случаях, когда дизайн исследования предполагает сравнение частоты носительства аллелей генов в группах больных псориатическим артритом и псориазом, возможны ошибки, вызванные включением в группу больных псориазом пациентов, у которых еще не развился 
псориатический артрит. Для минимизации ошибок такого рода в группу больных псориазом включают пациентов, у которых поражение кожи не сопровождается признаками псориатического артрита на протяжении не менее чем 10 лет [104].

Несмотря на установление ассоциации аллельных вариантов полиморфизмов определенных генов с развитием псориатического артрита, практически все такие генетические маркеры характеризуются низким или невысоким отношением шансов. Необходимо проведение дальнейших исследований на крупных выборках пациентов. Поскольку мультифакториальная природа псориатического артрита очевидна, использование новых биоинформатических подходов анализа полногеномных ассоциаций может выявить сочетанное влияние ряда геномных регионов, повысив уровень отношения шансов и улучшая показатели прогнозирования развития заболевания [105, 106].

\section{Литература/References}

1. Alinaghi F, Calov M, Kristensen LE, Gladman DD, Coates LC, Jullien $\mathrm{D}$, et al. Prevalence of psoriatic arthritis in patients with psoriasis: $A$ systematic review and meta-analysis of observational and clinical studies. J Am Acad Dermatol. 2019;80(1):251-265.e19.

doi: 10.1016/j.jaad.2018.06.027

2. Talotta R, Atzeni F, Sarzi-Puttini P, Masala IF. Psoriatic arthritis: from pathogenesis to pharmacologic management. Pharmacol Res. 2019;148:104394. doi: 10.1016/j.phrs.2019.104394

3. Kaeley GS, Eder L, Aydin SZ, Gutierrez M, Bakewell C. Enthesitis: A hallmark of psoriatic arthritis. Semin Arthritis Rheum. 2018;48(1):35-43. doi: 10.1016/j.semarthrit.2017.12.008

4. Szczerkowska-Dobosz A, Krasowska D, Bartosińska J, StawczykMacieja M, Walczak A, Owczarczyk-Saczonek A, et al. Pathogenesis of psoriasis in the "omic" era. Part IV. Epidemiology, genetics, immunopathogenesis, clinical manifestation and treatment of psoriatic arthritis. Postepy Dermatol Alergol. 2020;37(5):625-634.

doi: 10.5114/ada.2020.100478

5. Chimenti MS, Triggianese P, De Martino E, Conigliaro P, Fonti GL, Sunzini $F$, et al. An update on pathogenesis of psoriatic arthritis and potential therapeutic targets. Expert Rev Clin Immunol. 2019;15(8):823-836. doi: 10.1080/1744666X.2019.1627876

6. Belasco J, Wei N. Psoriatic arthritis: what is happening at the joint? Rheumatol Ther. 2019;6:305-315. doi: 10.1007/s40744-019-0159-1

7. Menon B, Gullick NJ, Walter GJ, Rajasekhar M, Garrood T, Evans $H G$, et al. Interleukin-17+ CD8+ T cells are enriched in the joints of patients with psoriatic arthritis and correlate with disease activity and joint damage progression. Arthritis Rheumatol. 2014;66(5):1272-1281. doi: 10.1002/art.38376

8. Tateiwa D, Yoshikawa H, Kaito T. Cartilage and bone destruction in arthritis: pathogenesis and treatment strategy: a literature review. Cells. 2019;8(8):818. doi: 10.3390/cells8080818

9. Soare A, Weber S, Maul L, Rauber S, Gheorghiu AM, Luber M, et al. Cutting edge: homeostasis of innate lymphoid cells is imbalanced in psoriatic arthritis. J Immunol. 2018;200(4):1249-1254.

doi: 10.4049/jimmunol.1700596

10. Agnesi F, Amrami KK, Frigo CA, Kaufman KR. Comparison of cartilage thickness with radiologic grade of knee osteoarthritis. SceletalRadiol. 2008;37(7):639-643. doi: 10.1007/s00256-008-0483-y

11. Bartosińska J, Michalak-Stoma A, Juszkiewicz-Borowiec $M$, Kowal M, Chodorowska G. The assessment of selected bone and cartilage biomarkers in psoriatic patients from Poland. Mediators Inflamm. 2015;2015:194535. doi: 10.1155/2015/194535

12. Yamashita T, Yao Z, Li F, Zhang Q, Badell IR, Schwarz EM, et al. $\mathrm{NF}-\kappa \mathrm{B}$ p50 and p52 regulate receptor activator of NF- $\kappa B$ ligand (RANKL) and tumor necrosis factor-induced osteoclast precursor differentiation by activating c-Fos and NFATc1. J Biol Chem. 2007;282(25):18245-18253. doi: 10.1074/jbc.M610701200
13. Sukhov A, Adamopoulos IE, Maverakis E. Interactions of the immune system with skin and bone tissue in psoriatic arthritis: a comprehensive review. Clin Rev Allergy Immunol. 2016;51(1):87-99. doi: 10.1007/s12016-016-8529-8

14. Nedeva IR, Vitale M, Elson A, Hoyland JA, Bella J. Role of OSCAR signaling in osteoclastogenesis and bone disease. Front Cell Dev Biol. 2021;9:641162. doi: 10.3389/fcell.2021.641162

15. Paine A, Ritchlin C. Bone remodeling in psoriasis and psoriatic arthritis: an update. CurrOpinRheumatol. 2016;28(1):66-75. doi: 10.1097/BOR.0000000000000232

16. Sakkas LI, Zafiriou E, Bogdanos DP. Mini review: new treatments in psoriatic arthritis. Focus on the IL-23/17 axis. Front Pharmacol. 2019;10:872. doi: 10.3389/fphar.2019.00872

17. Коротаева Т.В., Корсакова Ю.Л. Псориатический артрит: классификация, клиническая картина, диагностика, лечение. Научно-практическая ревматология. 2018;56(1):60-69. [Korotaeva TV, Korsakova YuL. Psoriatic arthritis: classification, clinical presentation, diagnosis, treatment. Nauchno-Prakticheskaya Revmatologiya = Rheumatology Science and Practice. 2018;56(1):60-69 (In Russ.)] doi: 10.14412/1995-4484-2018-60-69

18. Belinchón I, Salgado-Boquete L, López-Ferrer A, Ferran M, CotoSegura P, Rivera R, et al. Dermatologists' role in the early diagnosis of psoriatic arthritis: Expert recommendations. Actas Dermosifiliogr (Engl Ed). 2020;111(10):835-846. doi: 10.1016/j.ad.2020.06.004

19. McHugh NJ, Balachrishnan C, Jones SM. Progression of peripheral joint disease in psoriatic arthritis: a 5-yr prospective study. Rheumatology (0xford). 2003;42(6):778-783.

doi: 10.1093/rheumatology/keg217

20. Gladman DD, Shuckett R, Russell ML, Thorne JC, Schachter RK. Psoriatic arthritis (PSA): an analysis of 220 patients. Q J Med. 1987;62(238):127-141.

21. Gladman DD, Antoni C, Mease P, Clegg D0, Nash P. Psoriatic arthritis: Epidemiology, clinical features, course, and outcome. Ann Rheum Dis. 2005;64(Suppl. 2):ii14-ii17. doi: 10.1136/ard.2004.032482

22. Queiro-Silva R, Torre-Alonso JC, Tinturé-Eguren T, LypezLagunas I. A polyarticular onset predicts erosive and deforming disease in psoriatic arthritis. Ann Rheum Dis. 2003;62(1):68-70.

doi: 10.1136/ard.62.1.68

23. Kane D, Stafford L, Bresnihan B, FitzGerald 0. A prospective, clinical and radiological study of early psoriatic arthritis: an early synovitis clinic experience. Rheumatology (0xford). 2003;42(12):1460-1468. doi: 10.1093/rheumatology/keg384

24. Geijer M, Lindqvist $U$, Husmark T, Alenius GM, Larsson PT, Teleman A, et al. The Swedish early psoriatic arthritis registry 5-year followup: substantial radiographic progression mainly in men with high disease activity and development of dactylitis. J Rheumatol. 2015;42(11):2110 2117. doi: 10.3899/jrheum. 150165 
25. Haroon M, Gallagher P, FitzGerald O. Diagnostic delay of more than 6 months contributes to poor radiographic and functional outcome in psoriatic arthritis. Ann Rheum Dis. 2015;74(6):1045-1050.

doi: 10.1136/annrheumdis-2013-204858

26. Hile G, Kahlenberg JM, Gudjonsson JE. Recent genetic advances in innate immunity of psoriatic arthritis. Clin Immunol. 2020;214:108405. doi: 10.1016/j.clim.2020.108405

27. Loft ND, Skov L, Rasmussen MK, Gniadecki R, Dam TN, Brandslund I, et al. Genetic polymorphisms associated with psoriasis and development of psoriatic arthritis in patients with psoriasis. PLoS One. 2018;13(2):e0192010. doi: 10.1371/journal.pone.0192010

28. Aterido A, Cañete JD, Tornero J, Ferrándiz C, Pinto JA, Gratacós J, et al. Genetic variation at the glycosaminoglycan metabolism pathway contributes to the risk of psoriatic arthritis but not psoriasis. Ann Rheum Dis. 2019;78:214158. doi: 10.1136/annrheumdis-2018-214158

29. Zhang XY, Zhang HJ, Zhang Y, Fu YJ, He J, Zhu LP, et al. Identification and expression analysis of alternatively spliced isoforms of human interleukin-23 receptor gene in normal lymphoid cells and selected tumor cells. Immunogenetics. 2006;57(12):934-943.

doi: 10.1007/s00251-005-0067-0

30. Parham C, Chirica M, Timans J, Vaisberg E, Travis M, Cheung J, et al. A receptor for the heterodimeric cytokine IL-23 is composed of IL-12Rbeta1 and a novel cytokine receptor subunit, IL-23R. J Immunol. 2002;168(11):5699-5708. doi: 10.4049/jimmunol.168.11.5699

31. Stuart PE, Nair RP, Tsoi LC, Tejasvi T, Das S, Kang HM, et al. Genome-wide association analysis of psoriatic arthritis and cutaneous psoriasis reveals differences in their genetic architecture. Am J Hum Genet. 2015;97(6):816-836. doi: 10.1016/j.ajhg.2015.10.019

32. Budu-Aggrey A, Bowes J, Loehr S, Uebe S, Zervou MI, Helliwell P, et al. Replication of a distinct psoriatic arthritis risk variant at the IL23R locus. Ann Rheum Dis. 2016;75(7):1417-1418.

doi: 10.1136/annrheumdis-2016-209290

33. Zhu KJ, Zhu CY, Shi G, Fan YM. Association of IL23R polymorphisms with psoriasis and psoriatic arthritis: a meta-analysis. Inflamm Res. 2012;61(10):1149-1154. doi: 10.1007/s00011-012-0509-8.

34. Zwiers $A$, Kraal $L$, van de Pouw Kraan TC, Wurdinger $T$, Bouma G, Kraal G. Cutting edge: a variant of the IL-23R gene associated with infammatory bowel disease induces loss of microRNA regulation and enhanced protein production. J Immunol. 2012;188(4):1573-1577.

doi: 10.4049/jimmunol.1101494

35. Loures MAR, Alves HV, de Moraes AG, Santos TDS, Lara FF, Neves JSF, et al. Association of TNF, IL12, and IL23 gene polymorphisms and psoriatic arthritis: meta-analysis. Expert Rev Clin Immunol. 2019;15(3):303-313. doi: 10.1080/1744666X.2019.1564039

36. Sivanesan D, Beauchamp C, Quinou C, Lee J, Lesage S, Chemtob S, et al. IL23R (interleukin 23 receptor) variants protective against infammatory bowel diseases (IBD) display loss of function due to impaired protein stability and intracellular trafcking. J Biol Chem. 2016;291(16):8673-8685. doi: 10.1074/jbc.M116.715870

37. Abdo Al, Tye GJ. Interleukin 23 and autoimmune diseases: current and possible future therapies. Inflamm Res. 2020;69(5):463-480. doi: 10.1007/s00011-020-01339-9

38. Yang Q, Liu H, Qu L, Fu X, Yu Y, Yu G, et al. Investigation of 20 non-HLA (human leucocyte antigen) psoriasis susceptibility loci in Chinese patients with psoriatic arthritis and psoriasis vulgaris. Br J Dermatol. 2013;168(5):1060-1065. doi: 10.1111/bjd.12142

39. Wu Y, He X, Huang N, Yu J, Shao B. A20: a master regulator of arthritis. Arthritis Res Ther. 2020;22 (1):220. doi: 10.1186/s13075-020-02281-1

40. Martens A, van L00 G. A20 at the crossroads of cell death, inflammation, and autoimmunity. Cold Spring HarbPerspect Biol. 2020;12(1):a036418. doi: 10.1101/cshperspect.a036418

41. Catrysse L, Vereecke L, Beyaert R, van Lo0 G. A20 in inflammation and autoimmunity. Trends Immunol. 2014;35(1):22-31. doi: 10.1016/j.it.2013.10.005
42. Shembade N, Ma A, Harhaj EW. Inhibition of NF-kappaB signaling by $\mathrm{A} 20$ through disruption of ubiquitin enzyme complexes. Science. 2010;327(5969):1135-1139. doi: 10.1126/science.1182364

43. Wertz IE, O'Rourke KM, Zhou H, Eby M, Aravind L, Seshagiri S, et al. De-ubiquitination and ubiquitin ligase domains of A20 downregulate NF-kappaBsignalling. Nature. 2004;430(7000):694-699.

doi: 10.1038/nature02794

44. Shembade N, Harhaj EW. Regulation of NF-kappaB signaling by the A20 deubiquitinase. Cell Mol Immunol. 2012;9(2):123-130.

doi: $10.1038 / \mathrm{cmi} .2011 .59$

45. Lee EG, Boone DL, Chai S, Libby SL, Chien M, Lodolce JP, et al. Failure to regulate TNF-induced NF-kappaB and cell death responses in A20-deficient mice. Science. 2000;289 (5488):2350-2354.

doi: $10.1126 /$ science.289.5488.2350

46. Matmati $M$, Jacques $P$, Maelfait $J$, Verheugen $E$, Kool $M$, Sze M, et al. A20 (TNFAIP3) deficiency in myeloid cells triggers erosive polyarthritis resembling rheumatoid arthritis. Nat Genet. 2011;43(9):908912. doi: $10.1038 / \mathrm{ng} .874$

47. Cloutier JF, Veillette A. Cooperative inhibition of T-cell antigen receptor signaling by a complex between a kinase and a phosphatase. $J$ Exp Med.1999;189(1):111-121. doi: 10.1084/jem.189.1.111

48. Gjörloff-Wingren A, Saxena M, Williams S, Hammi D, Mustelin T. Characterization of TCRinduced receptor-proximal signaling events negatively regulated by the protein tyrosine phosphatase PEP. Eur $J$ Immunol. 1999;29(12):3845-3854.

doi: 10.1002/(SICI)1521-4141(199912)29:12<3845::AID-IMMU3845>3.0.C0;2-U

49. Stanford SM, Bottini N. PTPN22: the archetypal non-HLA autoimmunity gene. Nat Rev Rheumatol. 2014;10(10):602-611.

doi: 10.1038/nrrheum.2014.109

50. Rawlings DJ, Dai X, Buckner JH. The role of PTPN22 risk variant in the development of autoimmunity: finding common ground between mouse and human. J Immunol. 2015;194(7):2977-2984.

doi: 10.4049/jimmunol.1403034

51. Juneblad K, Johansson M, Rantapää-Dahlqvist S, Alenius GM. Association between the PTPN22 $+1858 \mathrm{C} / \mathrm{T}$ polymorphism and psoriatic arthritis. Arthritis Res Ther. 2011;13:R45. doi: 10.1186/ar3284

52. Bowes J, Loehr S, Budu-Aggrey A, Uebe S, Bruce IN, Feletar M, et al. PTPN22 is associated with susceptibility to psoriatic arthritis but not psoriasis: evidence for a further PsA-specific risk locus. Ann Rheum Dis. 2015;74(10):1882-1885. doi: 10.1136/annrheumdis-2014-207187

53. Tabata Y, Hershey GK. IL-13 receptor isoforms: breaking through the complexity. Curr Allergy Asthma Rep. 2007;7(5):338-345.

doi: 10.1007/s11882-007-0051-x

54. Spadaro A, Rinaldi T, Riccieri V, Valesini G, Taccari E. Interleukin 13 in synovial fluid and serum of patients with psoriatic arthritis. Ann Rheum Dis. 2002;61(2):174-176. doi: 10.1136/ard.61.2.174

55. Hart PH, Ahern MJ, Smith MD, Finlay-Jones JJ. Regulatory effects of IL-13 on synovial fluid macrophages and blood monocytes from patients with inflammatory arthritis. Clin Exp Immunol. 1995;99(3):331-337.

doi: 10.1111/j.1365-2249.1995.tb05554.x

56. Szodoray P, Alex P, Chappell-Woodward CM, Madland TM, Knowlton N, Dozmorov I, et al. Circulating cytokines in Norwegian patients with psoriatic arthritis determined by a multiplex cytokine array system. Rheumatology (0xford). 2007;46(3):417-425.

doi: 10.1093/rheumatology/kel306

57. Bessis N, Boissier MC, Ferrara P, Blankenstein T, Fradelizi D, Fournier $\mathrm{C}$. Attenuation of collagen-induced arthritis in mice by treatment with vector cells engineered to secrete interleukin-13. Eur $\mathrm{J}$ Immunol. 1996;26(10):2399-2403. doi: 10.1002/eji.1830261020

58. Eder L, Chandran V, Pellett F, Pollock R, Shanmugarajah S, Rosen CF, et al. IL13 gene polymorphism is a marker for psoriatic arthritis among psoriasis patients. Ann Rheum Dis. 2011;70(9):1594-1598. doi: 10.1136/ard.2010.147421 
59. Bowes J, Eyre S, Flynn E, Ho P, Salah S, Warren RB, et al. Evidence to support IL-13 as a risk locus for psoriatic arthritis but not psoriasis vulgaris. Ann Rheum Dis. 2011;70(6):1016-1019.

doi: 10.1136/ard.2010.143123

60. Duffin KC, Freeny IC, Schrodi SJ, Wong B, Feng BJ, SoltaniArabshahi R, et al. Association between IL13 polymorphisms and psoriatic arthritis is modified by smoking. J Invest Dermatol. 2009;129(12):27772783. doi: $10.1038 /$ jid.2009.169

61. Butt C, Gladman D, Rahman P. PPAR-gamma gene polymorphisms and psoriatic arthritis. J Rheumatol. 2006;33(8):1631-1633.

62. Jiang C, Ting AT, Seed B. PPAR-gamma agonists inhibit production of monocyte inflammatory cytokines. Nature. 1998;391(6662):82-86. doi: $10.1038 / 34184$

63. Keshamouni VG, Arenberg DA, Reddy RC, Newstead MJ, Anthwal S, Standiford TJ. PPAR-gamma activation inhibits angiogenesis by blocking ELR+CXC chemokine production in non-small cell lung cancer. Neoplasia. 2005;7(3):294-301. doi: 10.1593/ne0.04601

64. Bowes J, Ho P, Flynn E, Salah S, McHugh N, FitzGerald 0, et al. Investigation of IL1, VEGF, PPARG and MEFV genes in psoriatic arthritis susceptibility. Ann Rheum Dis. 2012;71(2):313-314.

doi: 10.1136/ard.2011.154690

65. Stuart PE, Nair RP, Ellinghaus E, Ding J, Tejasvi T, Gudjonsson JE, Li Y, et al. Genome-wide association analysis identifies three psoriasis susceptibility loci. Nat Genet. 2010;42(11):1000-1004. doi: $10.1038 / \mathrm{ng} .693$

66. Charo IF, Myers SJ, Herman A, Franci C, Connolly AJ, Coughlin SR. Molecular cloning and functional expression of two monocyte chemoattractant protein 1 receptors reveals alternative splicing of the carboxyl-terminal tails. Proc Natl Acad Sci USA. 1994;91(7):2752-2756. doi: 10.1073/pnas.91.7.2752

67. Sozzani S, Luini W, Borsatti A, Polentarutti N, Zhou D, Piemonti $L$, et al. Receptor expression and responsiveness of human dendritic cells to a defined set of CC and CXC chemokines. J Immunol. 1997;159(4):1993-2000

68. Weber KS, Nelson PJ, Gröne HJ, Weber C. Expression of CCR2 by endothelial cells: implications for MCP-1 mediated wound injury repair and in vivo inflammatory activation of endothelium. Arterioscler Thromb Vasc Biol. 1999;19(9):2085-2093. doi: 10.1161/01.atv.19.9.2085

69. Zheng Y, Qin L, Zacarías NV, de Vries H, Han GW, Gustavsson M, Dabros M, et al. Structure of CC chemokine receptor 2 with orthosteric and allosteric antagonists. Nature. 2016;540(7633):458-461.

doi: 10.1038/nature20605

70. Scholten DJ, Canals M, Maussang D, Roumen L, Smit MJ, Wijtmans $M$, et al. Pharmacological modulation of chemokine receptor function. Br J Pharmacol. 2012;165(6):1617-1643.

doi: 10.1111/j.1476-5381.2011.01551.x

71. Soto-Sánchez J, Santos-Juanes J, Coto-Segura P, Coto E, Díaz M, Rodríguez I, et al. Genetic variation at the CCR5/CCR2 gene cluster and risk of psoriasis and psoriatic arthritis. Cytokine. 2010;50(2):114-116. doi: 10.1016/j.cyto.2010.01.006

72. Bowes J, Budu-Aggrey A, Huffmeier U, Uebe S, Steel K, Hebert $\mathrm{HL}$, et al. Dense genotyping of immune-related susceptibility loci reveals new insights into the genetics of psoriatic arthritis. Nat Commun. 2015;6:6046. doi: 10.1038/ncomms7046

73. Becher B, Tugues S, Greter M. GM-CSF: from growth factor to central mediator of tissue inflammation. Immunity. 2016;45(5):963-973. doi: 10.1016/j.immuni.2016.10.026

74. Komuczki J, Tuzlak S, Friebel E, Hartwig T, Spath S, Rosenstiel P, et al. Fate-mapping of GM-CSF expression identifies a discrete subset of inflammation-driving T helper cells regulated by cytokines IL-23 and IL-1 $\beta$. Immunity. 2019;50(5):1289-1304.e6. doi: 10.1016/j.immuni.2019.04.006

75. Myllyharju J. Prolyl 4-hydroxylases, the key enzymes of collagen biosynthesis. Matrix Biol. 2003;22 (1):15-24.

doi: 10.1016/s0945-053x(03)00006-4
76. Aro E, Khatri R, Gerard-0'Riley R. Hypoxia-inducible factor-1 (HIF-1) but not HIF-2 is essential for hypoxic induction of collagen prolyl 4-hydroxylases in primary newborn mouse epiphyseal growth plate chondrocytes. J Biol Chem. 2012;287(44):37134-37144. doi: 10.1074/jbc.M112.352872

77. Gilkes DM, Bajpai S, Chaturvedi P, Wirtz D, Semenza GL. Hypoxiainducible factor 1 (HIF-1) promotes extracellular matrix remodeling under hypoxic conditions by inducing P4HA1, P4HA2, and PLOD2 expression in fibroblasts. J Biol Chem. 2013;288(15):10819-10829.

doi: 10.1074/jbc.M112.442939

78. Fähling M, Mrowka R, Steege A, Nebrich G, Perlewitz A, Persson PB, et al. Translational control of collagen prolyl 4-hydroxylasealpha(I) gene expression under hypoxia. J Biol Chem. 2006;281(36):2608926101. doi: 10.1074/jbc.M604939200

79. Lanier LL. NK cell recognition. Annu Rev Immunol. 2005;23:225274. doi: 10.1146/annurev.immunol.23.021704.115526

80. Chandran V, Bull SB, Pellett FJ, Ayearst R, Pollock RA, Gladman DD. Killer-cell immunoglobulin-like receptor gene polymorphisms and susceptibility to psoriatic arthritis. Rheumatology (Oxford). 2014;53(2):233-239. doi: 10.1093/rheumatology/ket296

81. Kulkarni S, Martin MP, Carrington M. The Yin and Yang of HLA and KIR in human disease. Semin Immunol. 2008;20(6):343-352. doi: 10.1016/j.smim.2008.06.003

82. Martin MP, Nelson G, Lee JH, Pellett F, Gao X, Wade J, et al. Cutting edge: susceptibility to psoriatic arthritis: influence of activating killer Ig-like receptor genes in the absence of specific HLA-C alleles. J Immunol. 2002;169(6):2818-2822. doi: 10.4049/jimmunol.169.6.2818

83. Williams F, Meenagh A, Sleator C, Cook D, Fernandez-Vina M, Bowcock AM, et al. Activating killer cell immunoglobulin-like receptor gene KIR2DS1 is associated with psoriatic arthritis. Hum Immunol 2005;66(7):836-841. doi: 10.1016/j.humimm.2005.04.005

84. Popa OM, Cherciu M, Cherciu LI, Dutescu Ml, Bojinca M, Bojinca $V$, et al. ERAP1 and ERAP2 gene variations influence the risk of psoriatic arthritis in Romanian population. Arch Immunol Ther Exp (Warsz). 2016;64(Suppl 1):123-129. doi: 10.1007/s00005-016-0444-4

85. Mpakali A, Giastas P, Mathioudakis N, Mavridis IM, Saridakis E, Stratikos E. Structural basis for antigenic peptide recognition and processing by endoplasmic reticulum (ER) aminopeptidase 2. J Biol Chem. 2015;290(43):26021-26032. doi: 10.1074/jbc.M115.685909

86. Andrés AM, Dennis MY, Kretzschmar WW, Cannons JL, LeeLin SQ, Hurle B, et al. Balancing selection maintains a form of ERAP2 that undergoes nonsense-mediated decay and affects antigen presentation. PLOS Genet. 2010;6(10):e1001157. doi: 10.1371/journal.pgen.1001157

87. Wiśniewski A, Matusiak $Ł$, Szczerkowska-Dobosz A, Nowak I, kuszczek W, Kuśnierczyk P. The association of ERAP1 and ERAP2 single nucleotide polymorphisms and their haplotypes with psoriasis vulgaris is dependent on the presence or absence of the HLA-C*06:02 allele and age at disease onset. Hum Immunol. 2018;79(2):109-116.

doi: 10.1016/j.humimm.2017.11.010

88. Julià A, Tortosa R, Hernanz JM, Cañete JD, Fonseca E, Ferrándiz $\mathrm{C}$, et al. Risk variants for psoriasisvulgaris in a large casecontrol collection and association withclinicalsubphenotypes. Hum Mol Genet. 2012;21(20):4549-4557. doi: 10.1093/hmg/dds29

89. GTEx Consortium. The Genotype-Tissue Expression (GTEx) project. Nat Genet. 2013;45:580-585. doi: 10.1038/ng.2653

90. Togayachi A, Kozono Y, Kuno A, Ohkura T, Sato T, Hirabayashi J, et al. Beta3GnT2 (B3GNT2), a major polylactosaminesynthase: analysis of B3GNT2-deficient mice. Methods Enzymol. 2010;479:185-204.

doi: 10.1016/S0076-6879(10)79011-X

91. Gulati K, Poluri KM. Mechanistic and therapeutic overview of glycosaminoglycans: the unsung heroes of biomolecular signaling. Glycoconj J. 2016;33(1):1-17. doi: 10.1007/s10719-015-9642-2

92. Schett G, Coates LC, Ash ZR, Finzel S, Conaghan PG. Structural damage in rheumatoid arthritis,psoriatic arthritis, and ankylosing spondylitis: 
traditional views, novel insights gainedfrom TNF blockade, and concepts for the future. Arthritis Res Ther. 2011;13(Suppl1):S4.

doi: 10.1186/1478-6354-13-S1-S4

93. Caterson B, Flannery CR, Hughes CE, Little CB. Mechanisms involved in cartilage proteoglycan catabolism. Matrix Biol. 2000;19(4):333344. doi: 10.1016/s0945-053x(00)00078-0

94. Arner EC, Hughes CE, Decicco CP, Caterson B, Tortorella MD. Cytokine-induced cartilage proteoglycandegradation is mediated by aggrecanase. Osteoarthritis Cartilage. 1998;6(3):214-228.

doi: 10.1053/joca.1998.0114

95. Sugimoto $K$, lizawa $T$, Harada $H$, Yamada $K$, Katsumata $M$, Takahashi M. Cartilage degradation independent of MMP/aggrecanases. Osteoarthritis Cartilage. 2004;12(12):1006-1014.

doi: 10.1016/j.joca.2004.09.003

96. Togayachi A, Kozono Y, Ishida H, Abe S, Suzuki N, Tsunoda Y, et al. Polylactosamine on glycoproteins influencesbasal levels of lymphocyte and macrophage activation. Proc Natl Acad Sci U S A. 2007;104(40):15829_ 15834. doi: 10.1073/pnas.0707426104

97. Budu-Aggrey A, Bowes J, Stuart PE, Zawistowski M, Tsoi LC, Nair $\mathrm{R}$, et al. A rare coding allele in IFIH1 is protective for psoriatic arthritis. Ann Rheum Dis. 2017;76(7):1321-1324.

doi: 10.1136/annrheumdis-2016-210592

98. Nejentsev S, Walker N, Riches D, Egholm M, Todd JA. Rare variants of $\mathrm{IFIH1}$, a geneimplicatedinantiviral responses, protect against type 1 diabetes. Science. 2009;324(5925):387-389.

doi: 10.1126/science. 1167728

99. Goubau D, Deddouche S, Reis e Sousa C. Cytosolic sensing of viruses. Immunity. 2013;38 (5):855-869. doi: 10.1016/j.immuni.2013.05.007
100. Rice Gl, Del Toro Duany $Y$, Jenkinson EM, Forte GM, Anderson BH, Ariaudo G, et al. Gain-of-function mutations in IFIH1 cause a spectrum of human disease phenotypes associated with upregulated type I interferon signaling. Nat. Genet. 2014;46(5):503-509. doi: 10.1038/ng.2933

101. Pollock RA, Abji F, Liang K, Chandran V, Pellett FJ, Virtanen C, et al. Gene expression differences between psoriasis patients with and without inflammatory arthritis. J Invest Dermatol. 2015;135(2):620-623. doi: 10.1038/jid.2014.414

102. Duan Z, Li FQ, Wechsler J. A novel notch protein, N2N, targeted by neutrophil elastase and implicated in hereditary neutropenia. Mol Cell Biol. 2004;24(1):58-70. doi: 10.1128/MCB.24.1.58-70.2004

103. Fukushima $H$, Nakao $A$, Okamoto $F$, Shin $M$, Kajiya $H$, Sakano S, et al. The association of Notch2 and NF-kappaB accelerates RANKL-induced osteoclastogenesis. Mol Cell Biol. 2008;28(20):6402-6412. doi: 10.1128/MCB.00299-08

104. Rahmati S, Tsoi L, O'Rielly D, Chandran V, Rahman P. Complexities in genetics of psoriatic arthritis. Curr Rheumatol Rep. 2020;22(4):10. doi: 10.1007/s11926-020-0886-x

105. Carvalho AL, Hedrich CM. The molecular pathophysiology of psoriatic arthritis - The complex interplay between genetic predisposition, epigenetics factors, and the microbiome. Front Mol Biosci. 2021;8:662047. doi: 10.3389/fmolb.2021.662047

106. Patrick MT, Stuart PE, Raja K, Gudjonsson JE, Tejasvi T, Yang $J$, et al. Genetic signature to provide robust risk assessment of psoriatic arthritis development in psoriasis patients. Nat Commun. 2018;9(1):4178. doi: 10.1038/s41467-018-06672-6

Участие авторов: все авторы внесли существенный вклад в проведение поисково-аналитической работы и подготовку статьи, прочли и одобрили финальную версию до публикации.

Концепция и дизайн статьи, одобрение окончательной версии статьи - А.А. Кубанов; концепция, дизайн, подготовка текста статьи - А.Э. Карамова; анализ литературы, сбор и обработка материала, написание текста статьи - В.В. Чикин; анализ литературы, сбор и обработка материала, подготовка текста статьи - Д.А. Вербенко; концепция, дизайн, подготовка текста статьи — Л.Ф. Знаменская; анализ литературы, сбор и обработка материала, написание текста статьи - О.Г. Артамонова.

Authors' participation: all authors made a significant contribution to the search and analytical work and preparation of the article, had read and approved the final version before publication.

Concept and design of the study, final approval for submission of the manuscript - Alexey A. Kubanov; concept and design of the study and preparation the text — Arfenya E. Karamova; analysis of literary data, collection and processing of material, preparation of the text — Vadim V. Chikin; analysis of literary data, collection and processing of material, preparation the text — Dmitry A. Verbenko; concept and design of the study and preparation the text — Lyudmila F. Znamenskaya; analysis of literary data, collection and processing of material, text writing — Olga G. Artamonova.

\section{Информация об авторах}

*Артамонова Ольга Григорьевна - младший научный сотрудник; адрес: Россия, 107076, Москва, улица Короленко, д. 3, стр. 6; ORCID iD: https://orcid.org/0000-0003-3778-4745; eLibrary SPIN: 3308-3330; e-mail: artamonova_olga@list.ru

Кубанов Алексей Алексеевич - д.м.н., профрессор, член-корреспондент PAH; ORCID iD: https://orcid.org/0000-0002-7625-0503; eLibrary SPIN: 8771-4990; e-mail: alex@cnikvi.ru

Карамова Арфеня Эдуардовна - к.M.H.; ORCID iD: https://orcid.org/0000-0003-3805-8489; eLibrary SPIN: 3604-6491; e-mail: karamova@cnikvi.ru

Чикин Вадим Викторович - д.м.н.; ORCID iD: https://orcid.org/0000-0002-9688-2727; eLibrary SPIN: 3385-4723; e-mail: chikin@cnikvi.ru

Вербенко Дмитрий Анатольевич — K.M.H.; ORCID iD: https://orcid.org/0000-0002-1104-7694; eLibrary SPIN: 8261-6561; e-mail: verbenko@gmail.com

Знаменская Людмила Федоровна — д.м.н.; ORCID iD: https://orcid.org/0000-0002-2553-0484; eLibrary SPIN: 9552-7850; e-mail: znaml@cnikvi.ru 


\section{Information about the authors}

*Olga G. Artamonova - junior research associate; address: 3 bld. 6, Korolenko street, 107076 Moscow, Russia; ORCID iD: https://orcid. org/0000-0003-3778-4745; eLibrary SPIN: 3308-3330; e-mail: artamonova_olga@list.ru

Alexey A. Kubanov - MD, Dr. Sci. (Med.), Professor, Corresponding Member of the Russian Academy of Sciences; ORCID iD: https://orcid.org/0000-0002-7625-0503; eLibrary SPIN: 8771-4990; e-mail: alex@cnikvi.ru

Arfenya E. Karamova - MD, Cand. Sci. (Med.); ORCID iD: https://orcid.org/0000-0003-3805-8489; eLibrary SPIN: 3604-6491; e-mail: karamova@cnikvi.ru

Vadim V. Chikin — MD, Dr. Sci. (Med.); ORCID iD: https://orcid.org/0000-0002-9688-2727; eLibrary SPIN: 3385-4723; e-mail: chikin@cnikvi.ru

Dmitry A. Verbenko - MD, Cand. Sci. (Med.); ORCID iD: https://orcid.org/0000-0002-1104-7694; eLibrary SPIN: 8261-6561; e-mail: verbenko@gmail.com

Lyudmila F. Znamenskaya - MD, Dr. Sci. (Med.); ORCID iD: https://orcid.org/0000-0002-2553-0484; eLibrary SPIN: 9552-7850; e-mail: znaml@cnikvi.ru

Статья поступила в редакцию: 02.07.2021

Принята к публикации: 05.08.2021

Дата публикации: 15.08.2021
Submitted: 02.07.2021

Accepted: 05.08.2021

Published: 15.08 .2021 